\title{
A Saudi G6PD Deficient Girl Died with Pediatric Multisystem Inflammatory Syndrome-COVID-19
}

Maryam A. Al-Aamri ${ }^{a}$, MBBS, SSCP, Fatimah T. Al-Khars, MBBS ${ }^{\text {a }}$, Sami J. Alkhwaitem ${ }^{\text {a }}$, MBBS, SSCP, Abdulaziz K. AlHassan a , MBBS, SSCP, Ali M. Al Aithan ${ }^{\mathrm{a}}$, MBBS, JBP, CABP, Fatima H. Alkhalifa ${ }^{a}$, MBBS, SSCP, Sameer Y. Al-Abdi ${ }^{\text {b,c, }}$, MBBS, JBP, CABP, SSCP, FRCPCH

\author{
Affiliations: \\ ${ }^{a}$ Department of Pediatrics, Maternity and Children Hospital, Al-Ahsa, Ministry of Health, \\ Saudi Arabia. \\ ${ }^{\mathrm{b}}$ Department of Pediatrics, King Abdulaziz Hospital, Ministry of the National Guard-Health \\ Affairs, Al-Ahsa, Saudi Arabia; ${ }^{\mathrm{C}}$ King Abdullah International Medical Research Center, Al- \\ Ahsa, Saudi Arabia; and ${ }^{\mathrm{d}}$ King Saud Bin Abdulaziz University for Health Sciences, Al-Ahsa, \\ Saudi Arabia
}

Address correspondence to: Sameer Al-Abdi, Department of Pediatrics, King Abdulaziz Hospital, Ministry of the National Guard-Health Affairs, Al-Ahsa, Saudi Arabia, [abdis@ngha.med.sa].

\begin{abstract}
Reports on pediatric multisystem inflammatory syndrome (PMIS) temporally related to coronavirus disease 2019 (COVID-19) are increasing. African and Afro-Caribbean children constituted about $37 \%$ of the cases in these reports. Although glucose-6-phosphatase dehydrogenase (G6PD) deficiency is common among this population, the G6PD status of these cases has not been reported. We report the first case of PMIS related to COVID-19 from Saudi Arabia. This case was a Saudi G6PD deficient girl who died with PMIS related to COVID-19. G6PD deficiency induces redox imbalance and exaggerates the inflammatory response; thus, it might contribute to the development or the grave outcome of our case. We urgently need to assess the association between G6PD deficiency and COVID-19 in a large study as the G6PD deficiency may be a useful predictor for the progression of the COVID19.

\section{Introduction}

Reports on pediatric multisystem inflammatory syndrome (PMIS), also known as a multisystem inflammatory syndrome in children, temporally related to coronavirus disease 2019 (COVID-19) are increasing. ${ }^{1-13}$ Data on race or ethnicity are available for 392 children with probable, possible, or confirmed PMIS related to COVID-19 in nine studies form Europe and USA. ${ }^{1-9}$ Pooled data show that the African and Afro-Caribbean or black children constituted $37 \%(144 / 392)$ of these cases. Four out of the five dead children whose race or ethnicity have been reported were black. ${ }^{1,2}$ Although glucose-6-phosphatase dehydrogenase (G6PD) deficiency is common among this population, ${ }^{14}$ the G6PD status of these cases has not been reported in these reports. We report the first case of PMIS related to COVID-19 from Saudi Arabia. This case was a previously healthy Saudi G6PD deficient girl.
\end{abstract}

\section{Case Report}

This case is a 10-15 years old previously healthy Saudi girl. She underwent a nasopharyngeal swab for acute respiratory syndrome coronavirus 2 (SARS-CoV-2) during a COVID-19 
contact tracing process. Her reverse transcription-polymerase chain reaction (RT-PCR) reported positive for SARS-CoV-2. She was asymptomatic for 22 days, and then she started to have a fever, abdominal pain, vomiting, and diarrhea. Two days later, she presented to our emergency room with a clinical picture similar to Kawasaki disease shock syndrome. She rapidly developed multiple organ dysfunction syndrome and succumbed to death despite aggressive medical support. Figure 1 and Table 1 summarize timeline events, investigations, and management of the case.

\section{Discussion}

We report a previously healthy Saudi G6PD deficient girl who died with PMIS after 23 days of being diagnosed as asymptomatic COVID-19.

Our case fulfilled the case definition of PMIS related to COVID-19. ${ }^{15-17}$ Our case aged 10-15 years old, had persistent temperature $>38 \square \mathrm{C}$ for $\geq 3$ days, acute gastrointestinal problems, clinical features similar to Kawasaki disease, hypotension, shock, myocardial dysfunction, elevated markers of inflammation, evidence of COVID-19, and no plausible alternative diagnoses. The PMIS related to COVID-19 in our case manifested 23 days after confirmed asymptomatic COVID-19. The nasopharyngeal swab of our case continued to be positive for at least 25 days. Her tracheal aspirate sample, which its yield is better than other respiratory swabs, ${ }^{18}$ was negative for COVID-19 after seven days of the PMIS related to COVID-19. We are fairly sure that the two nasopharyngeal swabs were true positive as nasopharyngeal swabs of all her household were positive. These observations confirm that PMIS is delayed inflammatory response after COVID-19., 12

Our case is the first case of PMIS related to COVID-19 reported in Arabs ethnicity. This syndrome has been reported in Middle Eastern decants living in Europe. ${ }^{13-5}$ However, the Middle East has many different ethnicities, which have not been reported by these studies. The fluorescent spot test (FST) for G6PD screening was positive in our case. This result suggests that our case had a moderate to severe G6PD deficiency as the upper cut-off of our FST is 2.1 Units/ gram Hemoglobin. ${ }^{19}$ This G6PD deficiency makes our case exceptional. African and Afro-Caribbean children overrepresented in reports that have data on race or ethnicity. ${ }^{1-9}$ Although glucose-6-phosphatase dehydrogenase (G6PD) deficiency is common among this population, ${ }^{14}$ the G6PD status of these cases has not been reported in these reports.

G6PD deficiency might contribute to the development of PMIS related to COVID-19 and the grave outcome of our case. G6PD enzyme is present in all body cells, including breast milk. ${ }^{20,21}$ Redox has a vital part in the modulation of inflammation and immune response. ${ }^{22}$ The G6PD deficiency induces redox imbalance, which exaggerates the inflammatory response. ${ }^{22}$ An ex vivo stud showed that pro-inflammatory interleukin (IL)-8 is upregulated by G6PD deficiency. ${ }^{22}$ The duration of systemic inflammatory response syndrome after major trauma is significantly longer in G6PD-deficient patients compared to their G6PD normal counterpart. ${ }^{14}$ Increased hydrogen peroxide in monocytes of G6PD-deficient major trauma victims has been documented. ${ }^{14}$ Hydrogen peroxide activates pro-inflammatory tumor necrosis factor-alpha (TNF- $\alpha){ }^{22}$ A recent study suggests that hydrogen peroxide is the first pro-inflammatory messenger. ${ }^{23}$ Monocytes of G6PD deficient major trauma victims have shown to have increased activity and reduced spontaneous apoptosis. ${ }^{14}$ Reduced antiinflammatory IL-10 level has been evident in monocytes and plasma of type A- G6PD deficient major trauma victims and in Mediterranean G6PD deficient individuals. ${ }^{14,24,25}$ It has been shown that alleles of low-producing IL-10, high-producing pro-inflammatory IL-6, and low-producing pro-inflammatory interferon- $\gamma$ are predominant in G6PD-deficient trauma 
medRxiv preprint doi: https://doi.org/10.1101/2020.07.08.20137497; this version posted July 11, 2020. The copyright holder for this preprint (which was not certified by peer review) is the author/funder, who has granted medRxiv a license to display the preprint in perpetuity.

It is made available under a CC-BY-NC 4.0 International license.

victims. ${ }^{26}$ Interestingly, it has been demonstrated that ex vivo production of TNF- $\alpha$, IL- 6 , and IL-10 in G6PD deficient and G6PD normal infants are the same. ${ }^{27}$ Moreover, the G6PD level is known to decrease with age. ${ }^{28}$ These observations may contribute to why PMIS related to COVID-19 has not been reported in infants yet. G6PD deficiency may be a useful predictor for the progression of the COVID-19. Thus, we urgently need to assess the association between G6PD deficiency and COVID-19 in a large study.

In summary, we report a previously healthy Saudi G6PD Deficient Girl who died with PMIS temporally related to COVID-19. G6PD deficiency may be a useful predictor for the progression of the COVID-19. We believe the association between G6PD deficiency and COVID-19 deserves further study.

\section{Conflict of Interest Disclosures (includes financial disclosures):}

All authors have no example conflicts of interest to disclose.

\section{Funding/Support:}

No funding was secured for this study

\section{Condolence}

We want to express our sincere condolences to the parent and family.

Figure 1. Timeline events for the case.

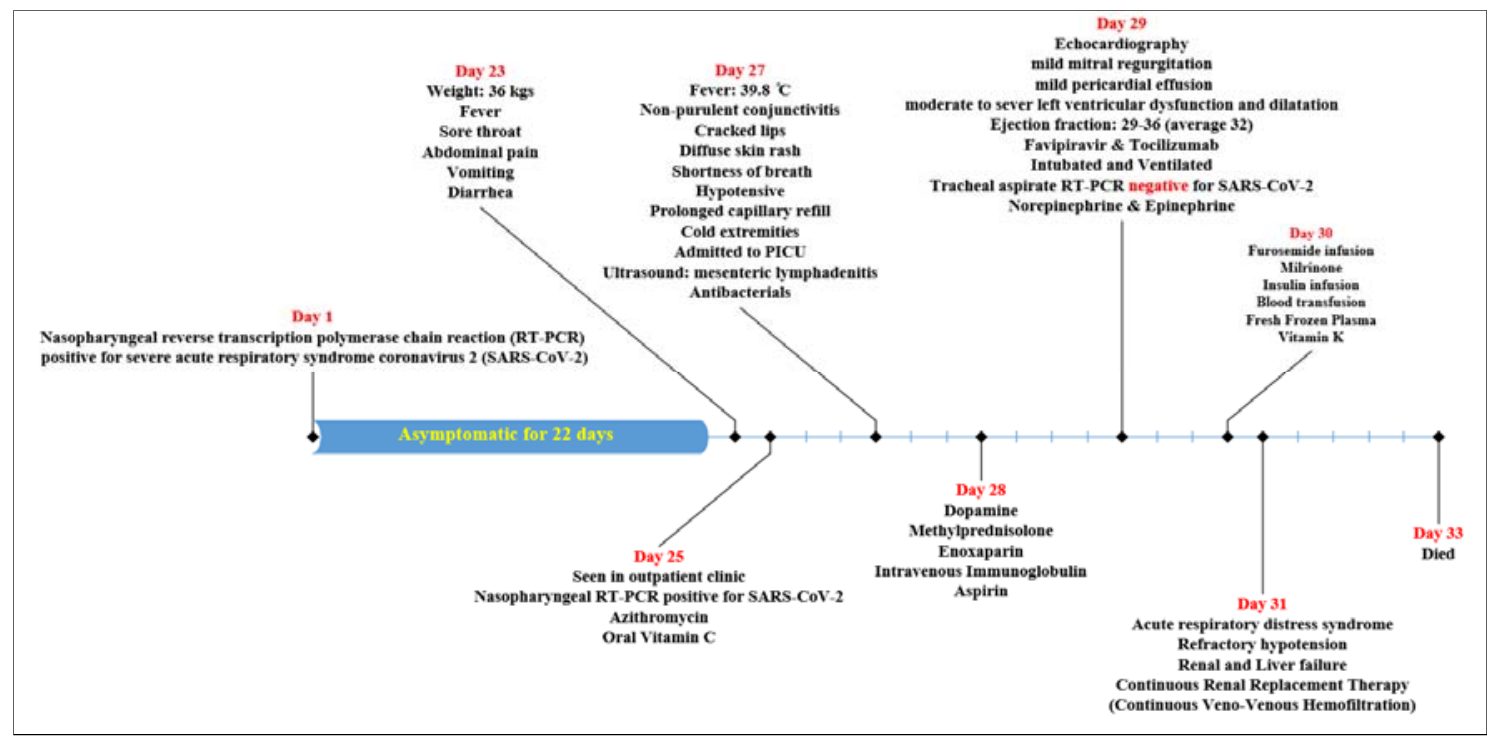

Table 1. Results of Blood investigations.

\begin{tabular}{|l|l|l|l|}
\hline Investigations $^{\mathrm{a}}$ & Our reference range & Lowest value & Highest value \\
\hline $\begin{array}{l}\text { G6PD Fluorescent spot test } \\
\text { (one measurement) }\end{array}$ & $\begin{array}{l}\text { Upper cut-off is 2.1 Units/ } \\
\text { gram Hemoglobin }\end{array}$ & Positive (deficient) \\
\hline Total white blood cells & $5-15 \times 10^{3} / \mu \mathrm{L}$ & 10.56 & 33.36 \\
\hline
\end{tabular}


medRxiv preprint doi: https://doi.org/10.1101/2020.07.08.20137497; this version posted July 11, 2020. The copyright holder for this preprint (which was not certified by peer review) is the author/funder, who has granted medRxiv a license to display the preprint in perpetuity.

It is made available under a CC-BY-NC 4.0 International license .

\begin{tabular}{|c|c|c|c|}
\hline Hemoglobin & $10.5-14.0 \mathrm{~g} / \mathrm{dL}$ & 7.6 & 10.2 \\
\hline Platelet & $150-400 \times 10^{3} / \mu \mathrm{L}$ & 170 & 375 \\
\hline Urea & $1.7-8.30 \mathrm{mmol} / \mathrm{L}$ & 3.6 & 20.7 \\
\hline Creatinine & $53-115 \mu \mathrm{mol} / \mathrm{L}$ & 59.6 & 502 \\
\hline Random serum glucose & $74-160 \mathrm{mg} / \mathrm{dL}$ & 127 & 460 \\
\hline Sodium & $135-145 \mathrm{mmol} / \mathrm{L}$ & 127 & 137 \\
\hline Potassium & $3.5-5 \mathrm{mmol} / \mathrm{L}$ & 3.0 & 4.1 \\
\hline Chloride & 95-115 mmol/L & 89 & 103 \\
\hline Magnesium & $0.60-1.2 \mathrm{mmol} / \mathrm{L}$ & 0.70 & 0.98 \\
\hline Calcium & $2.1-2.6 \mathrm{mmol} / \mathrm{L}$ & 1.71 & 2.10 \\
\hline Phosphate & $0.81-1.85 \mathrm{mmol} / \mathrm{L}$ & 0.63 & 2.26 \\
\hline Lactate dehydrogenase & 100-190 units/L & 193 & 5528 \\
\hline Total serum bilirubin & $0.2-1.0 \mathrm{mg} / \mathrm{dL}$ & 0.754 & 6.23 \\
\hline Direct bilirubin & $0.0-0.2 \mathrm{mg} / \mathrm{dL}$ & 0.26 & 4.46 \\
\hline Albumin & $34.0-50.0 \mathrm{~g} / \mathrm{L}$ & 17.7 & 27.3 \\
\hline $\begin{array}{l}\text { Aspartate aminotransferase } \\
\text { (Only two measurement in the first } \\
\text { two days) }\end{array}$ & 15-37 units/L & 29.5 & 168 \\
\hline Alanine Aminotransferase & $14-59$ units/L & 25.5 & 1490 \\
\hline Alkaline phosphatase & 46-116 units/L & 110 & 119 \\
\hline Prothrombin time & $11.0-13.5$ seconds & 16.1 & 24.4 \\
\hline Partial thromboplastin time & $30-40$ seconds & 38.1 & 78.3 \\
\hline International normalized ratio & $0.8-1.1$ & 1.40 & 2.17 \\
\hline $\mathrm{Ph}$ & $7.35-7.45$ & 7.06 & 7.32 \\
\hline $\mathrm{PvCO}_{2}$ & $41-51 \mathrm{mmHg} / \mathrm{L}$ & 43 & 93.6 \\
\hline Bicarbonate & $21-27 \mathrm{mmol} / \mathrm{L}$ & 14.0 & 21.0 \\
\hline Methemoglobin Fraction & $0-3 \%$ & $0.5 \%$ & $1.9 \%$ \\
\hline Erythrocyte sedimentation rate & $0.0-29 \mathrm{~mm} / \mathrm{hour}$ & 8 & 110 \\
\hline Ferritin (one measurement) & $12-150 \mathrm{ng} / \mathrm{mL}$ & 805 & \\
\hline c-reactive protein & \multicolumn{3}{|c|}{ Not measured as the reagent was not available } \\
\hline Creatine kinase (one measurement) & 30-35 units/L & \multicolumn{2}{|c|}{178} \\
\hline $\begin{array}{l}\text { Creatine kinase-MB (one } \\
\text { measurement) }\end{array}$ & 5-25 units/L & 2034 & \\
\hline Cytomegalovirus antibodies & \multirow{4}{*}{ Negative } & \multirow{4}{*}{\multicolumn{2}{|c|}{ Negative }} \\
\hline Herpes simplex virus antibodies & & & \\
\hline Epstein-Barr virus antibodies & & & \\
\hline Blood, Tracheal, and Urine cultures & & & \\
\hline
\end{tabular}


medRxiv preprint doi: https://doi.org/10.1101/2020.07.08.20137497; this version posted July 11, 2020. The copyright holder for this preprint (which was not certified by peer review) is the author/funder, who has granted medRxiv a license to display the preprint in perpetuity. It is made available under a CC-BY-NC 4.0 International license.

${ }^{a}$ We performed the blood investigations at least once a day unless specified.

\section{References}

1. Riphagen S, Gomez X, Gonzalez-Martinez C, Wilkinson N, Theocharis P. Hyperinflammatory shock in children during COVID-19 pandemic. The Lancet. 2020;395(10237):1607-1608.

2. Feldstein LR, Rose EB, Horwitz SM, Collins JP, Newhams MM, Son MBF, et al. Multisystem Inflammatory Syndrome in U.S. Children and Adolescents. New England Journal of Medicine. 2020.

3. Whittaker E, Bamford A, Kenny J, Kaforou M, Jones CE, Shah P, et al. Clinical Characteristics of 58 Children With a Pediatric Inflammatory Multisystem Syndrome Temporally Associated With SARS-CoV-2. JAMA. 2020.

4. Toubiana J, Poirault C, Corsia A, Bajolle F, Fourgeaud J, Angoulvant F, et al. Kawasaki-like multisystem inflammatory syndrome in children during the covid-19 pandemic in Paris, France: prospective observational study. BMJ. 2020;369:m2094.

5. Pouletty M, Borocco C, Ouldali N, Caseris M, Basmaci R, Lachaume N, et al. Paediatric multisystem inflammatory syndrome temporally associated with SARSCoV-2 mimicking Kawasaki disease (Kawa-COVID-19): a multicentre cohort. Annals of the Rheumatic Diseases. 2020:annrheumdis-2020-217960.

6. Dufort EM, Koumans EH, Chow EJ, Rosenthal EM, Muse A, Rowlands J, et al. Multisystem Inflammatory Syndrome in Children in New York State. New England Journal of Medicine. 2020.

7. Cheung EW, Zachariah P, Gorelik M, Boneparth A, Kernie SG, Orange JS, et al. Multisystem Inflammatory Syndrome Related to COVID-19 in Previously Healthy Children and Adolescents in New York City. JAMA. 2020.

8. Miller J, Cantor A, Zachariah P, Ahn D, Martinez M, Margolis K. Gastrointestinal symptoms as a major presentation component of a novel multisystem inflammatory syndrome in children (MIS-C) that is related to COVID-19: a single center experience of 44 cases. Gastroenterology. 2020;4(20):34753-34753.

9. Capone CA, Subramony A, Sweberg T, Schneider J, Shah S, Rubin L, et al. Characteristics, Cardiac involvement, and Outcomes of Multisystem Inflammatory Disease of Childhood (MIS-C) Associated with SARS-CoV-2 Infection: J Pediatr. 2020 Jun 14:S0022-3476(20)30746-0. doi: 10.1016/j.jpeds.2020.06.044.; 2020.

10. Verdoni L, Mazza A, Gervasoni A, Martelli L, Ruggeri M, Ciuffreda M, et al. An outbreak of severe Kawasaki-like disease at the Italian epicentre of the SARS-CoV-2 epidemic: an observational cohort study. The Lancet. 2020;395(10239):1771-1778. 
11. Belhadjer Z, Méot M, Bajolle F, Khraiche D, Legendre A, Abakka S, et al. Acute heart failure in multisystem inflammatory syndrome in children (MIS-C) in the context of global SARS-CoV-2 pandemic. Circulation. 2020;0(0).

12. Belot A, Antona D, Renolleau S, Javouhey E, Hentgen V, Angoulvant F, et al. SARSCoV-2-related paediatric inflammatory multisystem syndrome, an epidemiological study, France, 1 March to 17 May 2020. Eurosurveillance. 2020;25(22):2001010.

13. Grimaud M, Starck J, Levy M, Marais C, Chareyre J, Khraiche D, et al. Acute myocarditis and multisystem inflammatory emerging disease following SARS-CoV-2 infection in critically ill children. Ann Intensive Care. 2020;10(1):020-00690.

14. Spolarics Z, Siddiqi M, Siegel JH, Garcia ZC, Stein DS, Ong H, et al. Increased incidence of sepsis and altered monocyte functions in severely injured type Aglucose-6-phosphate dehydrogenase-deficient African American trauma patients. Crit Care Med. 2001;29(4):728-736.

15. Royal College of Paediatrics and Child Health. Guidance: paediatric multisystem inflammatory syndrome temporally associated with COVID-19. https://www.rcpch.ac.uk/resources/guidance-paediatric-multisystem-inflammatorysyndrome-temporally-associated-covid-19-pims. Published 1 May, 2020. Accessed 19 June, 2020.

16. Centers for Disease Control and Prevention. Emergency preparedness and response: health alert network. https://emergency.cdc.gov/han/2020/han00432.asp. Published 14 May, 2020. Accessed 19 June, 2020.

17. World Health Organization. Multisystem inflammatory syndrome in children and adolescents with COVID-19. https://www.who.int/publications/i/item/multisysteminflammatory-syndrome-in-children-and-adolescents-with-covid-19. Published 15 May, 2020. Accessed 19 June, 2020.

18. Wang W, Xu Y, Gao R, Lu R, Han K, Wu G, et al. Detection of SARS-CoV-2 in Different Types of Clinical Specimens. JAMA. 2020;323(18):1843-1844.

19. Al-Abdi SY, Alsaigh AS, Aldawoud FL, Al Sadiq AA. Lower reference limits of quantitative cord glucose-6-phosphate dehydrogenase estimated from healthy term neonates according to the clinical and laboratory standards institute guidelines: a cross sectional retrospective study. BMC pediatrics. 2013;13(1):137.

20. Wilmanski J, Siddiqi M, Deitch EA, Spolarics Z. Augmented IL-10 production and redox-dependent signaling pathways in glucose-6-phosphate dehydrogenase-deficient mouse peritoneal macrophages. J Leukoc Biol. 2005;78(1):85-94.

21. Al-Abdi S, Al-Abdi J, Al-Aamri M. Similarity Index Between Breast Milk and Infant Formula. EC Paediatrics. 2017;6.4:91-111.

22. Yang H-C, Cheng M-L, Hua Y-S, Wu Y-H, Lin H-R, Liu H-Y, et al. Glucose 6phosphate dehydrogenase knockdown enhances IL-8 expression in HepG2 cells via oxidative stress and NF- $\kappa \mathrm{B}$ signaling pathway. Journal of Inflammation. 2015;12(1):34. 
23. Gunawardena D, Raju R, Münch G. Hydrogen peroxide mediates pro-inflammatory cell-to-cell signaling: a new therapeutic target for inflammation? Neural Regen Res. 2019;14(8):1430-1437.

24. Liese AM, Siddiqi MQ, Siegel JH, Deitch EA, Spolarics Z. Attenuated monocyte IL10 production in glucose-6-phosphate dehydrogenase-deficient trauma patients. Shock. 2002;18(1):18-23.

25. Mordmüller B, Turrini F, Long H, Kremsner PG, Arese P. Neutrophils and monocytes from subjects with the Mediterranean G6PD variant: effect of Plasmodium falciparum hemozoin on G6PD activity, oxidative burst and cytokine production. European Cytokine Network. 1998;9(3):239-246.

26. Upperman JS, Pillage G, Siddiqi MQ, Zeevi A, Kelly N, Ford HR, et al. Dominance of high-producing interleukin 6 and low-producing interleukin 10 and interferon gamma alleles in glucose-6-phosphate dehydrogenase-deficient trauma patients. Shock. 2005;23(3):197-201.

27. Liao SL, Lai SH, Tsai MH, Weng YH. Cytokine responses of TNF- $\alpha$, IL-6, and IL-10 in G6PD-deficient infants. Pediatr Hematol Oncol. 2014;31(1):87-94.

28. Yang W-C, Tai S, Hsu C-L, Fu C-M, Chou A-K, Shao P-L, et al. Reference levels for glucose-6-phosphate dehydrogenase enzyme activity in infants 7-90 days old in Taiwan. Journal of the Formosan Medical Association. 2020;119(1, Part 1):69-74. 